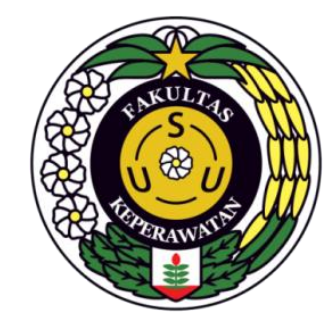

KAJIAN ILMIAH

\title{
PERAN KEPALA RUANGAN DALAM PENGEMBANGAN DOKUMENTASI KEPERAWATAN SECARA ELEKTRONIK UNTUK MENINGKATKAN MUTU PELAYANAN KEPERAWATAN
}

\section{DISUSUN OLEH :}

RINI DEBORA SILALAHI (197046015)

rinisilalahi19@gmail.com

\author{
PROGRAM STUDI MAGISTER ILMU KEPERAWATAN \\ FAKULTAS KEPERAWATAN \\ UNIVERSITAS SUMATERA UTARA \\ 2019
}




\title{
PERAN KEPALA RUANGAN DALAM PENGEMBANGAN DOKUMENTASI KEPERAWATAN SECARA ELEKTRONIK UNTUK MENINGKATKAN MUTU PELAYANAN KEPERAWATAN
}

\author{
Rini Debora Silalahi \\ Program Studi Magister Keperawatan Fakultas Keperawatan Universitas Sumatera Utara
}

\begin{abstract}
ABSTRAK
Dalam era 4.0, rumah sakit dituntut untuk meningkatkan kinerja serta mampu merumuskan kebijakankebijakan strategis antara lain efisiensi dari dalam (organisasi, manajemen, serta SDM) serta harus mampu secara cepat dan tepat mengambil keputusan untuk peningkatan pelayanan kepada masyarakat agar dapat menjadi organisasi yang inovatif, efektif, efisien, menguntungkan juga tanggap terhadap perkembangan IPTEK termasuk teknologi informasi. Teknologi informatika keperawatan sudah saatnya diterapkan di pelayanan kesehatan Indonesia. Sebagai contoh dalam melakukan dokumentasi pasien. Selama ini penerapannya terhambat karena ketidaksiapan sumber daya manusia, dan rutinitas perawat yang membuat malas berubah. Penerapan dokumentasi elektronik di pelayanan keperawatan akan menghemat tenaga, biaya, dan waktu. Penerapan dokumentasi elektronik keperawatan bukan hal yang tidak mungkin dilaksanakan, jika dilakukan dengan sepenuh hati dan bekerjasama dengan semua pihak yang terkait mulai dari pihak managerial, perawat pelaksana, tim kesehatan lain, pasien, dan tenaga ahli teknologi informatika.
\end{abstract}

Kata Kunci : Kepala Ruangan, Dokumentasi Elektronik, Mutu Layanan Keperawatan

\section{A. Latar Belakang}

Kesiapan penerapan teknologi informasi di bidang keperawatan merupakan suatu hal yang diperlukan saat ini. Dokumentasi yang cukup banyak mulai dari pencatatan data pasien, asuhan keperawatan, administrasi keuangan, catatan medis, catatan data penunjang akan terasa ringan jika dikomputerisasikan. Model komputerisasi yang digunakan saat ini sudah mulai berkembang dengan kegiatan yang meminimalkan kerja perawat dalam mencatat manual dan memaksimalkan upaya yang dilakukan untuk melakukan pelayanan keperawatan.

Hal yang perlu dipersiapkan untuk memulainya mungkin cukup berat antara lain dengan persiapan software computer dan program yang dikerjakan bersama teman-teman dari teknologi informatika; pelatihan SDM perawat yang akan melakukan kegiatan, pihak manajerial sebagai pemegang keputusan akan sangat menentukan keberhasilan program. Upaya yang dilakulan dalam penerapan model-model pendokumentasian elektronik dapat 
dilakukan dengan memperhatikan beberapa hal yakni pengetahuan perawat, kemampuan perawat setelah mengetahui, dan kemauan perawat untuk bekerja keras melaksanakan program. Perawat pada umumnya sulit untuk diajak berkembang, dan keadaan ini harus diimbangi dengan upaya managerial untuk mensupport terlaksananya program melalui program pelatihan, reward and punishment.

Dengan berjalannya waktu makadiikuti dengan berkembangnya teknologi, sehingga memampukan perawat untuk dapat menggunakan waktu kerja lebih efisien. Dengan adanya dokumentasi elektronik maka perawat dapat memiliki waktu yang lebih banyak lagi untuk dapat memperhatikan pasien. Sehingga perawat tidak lagi terbebani oleh tugas non keperawatan. Dalam program ini dibutuhkan kerjasama oleh semua pihak. Jika setiap perawat mampu mengambil bagian untuk perubahan maka dapat menciptakan kualitas pelayanan keperawatan yang lebih baik lagi.

\section{B. Tujuan}

Tujuan kajian ini adalah untuk melihat bagaimana peran kepala ruangan dalam pengembangan dokumentasi elektronik.

\section{Metode}

Kajian ini dilakukan dengan mencari sumber data baik dari jurnal maupun bukubuku yang berhubungan dengan peran kepala ruangan dalam pengembangan dokumentasi elektronik.. Artikel penelitian yang digunakan bersumber dari Repository USU, Google Scholar. Penelusuran dilakukan dengan kata kunci sesuai dengan topik yaitu kepemimpinan, peran kepala ruangan, budaya keselamatan pasien.

\section{Hasil}

Bedasarkan dari beberapa sumber didapatkan hasil bahwa pengembangan dokumentasi elektronik dapat meringankan beban kerja perawat. Penerapan dokumentasi keperawatan berbasis elektronik bukan suatu hal yang tidak mungkin dilaksanakan, jika dilakukan dengan sepenuh hati dan bekerjasama dengan semua pihak yang terkait mulai dari pihak managerial, perawat pelaksana, tim kesehatan yang lain, pasien, dan tenaga ahli teknologi informatika. Penyelenggaraan dengan dana besar diawal akan sebanding dengan manfaat jangka panjang. Hal tersebut berkaitan dengan kualitas sumber daya manusia, 
kualitas pendokumentasian keperawatan, kualitas pengembangan teknologi informatika, penghematan tenaga, kualitas kinerja perawat, dan penghematan biaya operasional. Penerapan teknologi informasi dalam bidang keperawatan justru akan memberikan nilai lebih dalam pelaksanaan pelayanan keperawatan. Penerapan dokumentasi elektronik diharapkan dapat memfasilitasi kinerja perawat yang cukup waktu dan tenaga untuk dapat melaksanakan kegiatan pelayanan keperawatan.

\section{E. Pembahasan}

Dokumentasi pasien yang terkomputerisasi (computerized patient records) mengalami perkembangan pesat, sehingga perlu diciptakan tata bahasa baku dalam menggambarkan masalah-masalah pasien yang dapat dipahami secara universal dan konsisten diantara para perawat (Doenges et al. 1999). Pembakuan bahasa dan model pencatatan yang disepakati harus yang dikuasai oleh pelaksana dokumentasi, seperti jika perawat memutuskan pendokumentasian pengkajian keperawatan berdasar teori 'orem' maka perawat harus tahu tentang penerapannya dalam pendokumentasian. Termasuk pendokumentasian diagnosa keperawatan menurut NANDA/Carpenito/Doengoes atau lainnya, intervensi keperawatan dengan NOC dan NIC, implementasi keperawatan berdasarkan waktu, dan evaluasi dalam bentuk SOAP.

Sistem informasi yang terintegrasi akan memudahkan setiap tim kesehatan untuk dapat mengetahui informasi pasien dan juga rencana pengobatan maupun perawatan berdasarkan apa yang terjadi pada saat itu dan apa rencana yang diinginkan di kemudian hari. Perawatan pasien akan lebih baik dikarenakan akan mengurangi pengumpulan data secara berulang -ulang yang dilakukan oleh setiap tim kesehatan (Yoder-Wise, 2011).

Tantangan yang berat dalam informatika kesehatan adalah disepakatinya standar klasifikasi dan terminologi yang mencakup berbagai konsep (kedokteran, keperawatan, laboratorium, obat, patient safety, images, pertukaran data, demografis). Hal ini menguntungkan setiap tenaga kesehatan dalam rumah sakit. Secara sistem keseluruhan akan terdokumentasi dengan software yang lengkap. Khususnya dokumentasi asuhan keperawatan harus ada standar baku yang disetting berdasarkan model tertentu. 
Pendokumentasin pengkajian keperawatan yang sudah dilaksanakan di Indonesia adalah model sistem, divisi doengoes, dan model kebutuhan dasar. Sebanyak apapun kegiatan yang kita lakukan bila tanpa pendokumentasian maka akan mengurangi manfaat. Kerjakan apa yang kita dokumentasikan dan dokumentasikan apa yang kita lakukan. Selama ini sediaan software pengkajian belum dispesifikan pada kondisi-kondisi tertentu, pendokumentasian yang lebih spesifik mungkin lebih rumit bagi programer namun akan memudahkan kerja perawat dalam memilih option pendokumentasian.

Penerapan sistem informasi keperawatan terkomputerisasi terkait intervensi yang dilakukan di beberapa RS di Indonesia diharapkan spesifik mulai dari Nursing Out Come (NOC) yang baku klasifikasi dan jelas kriterianya; Nursing Intervention Clasification (NIC) disusun secara baku pada setiap klasifikasinya dan disesuaikan juga dengan klasifikasi tujuan (NOC). Sehingga perawat tinggal memilih label NIC yang tersedia pada masingmasing diagnosa keperawatan yang sesuai dengan tujuan penanganan masalah pasien. Implementasi keperawatan dalam sistem informasi keperawatan menggunakan label NIC dan aktifitas dalam NIC. Perawat tinggal mengetikan aktifitas-aktifitas perawatan yang telah dilakukan, menambahkan jam pelaksanaan dan menuliskan pelaksana dari aktifitas tersebut. Implementasi yang diinputkan oleh perawat dalam dokumen asuhan keperawatan langsung diintegrasikan dengan Billing System Rumah Sakit, sehingga tidak ada double entry dalam keuangan pasien. Masing masing tindakan perawat telah memiliki harga sendiri sendiri yang telah disahkan oleh rumah sakit, dan perawat tinggal mendokumentasikan dalam SI Keperawatan. Artinya penulisan implementasinya juga dibakukan sehingga perawat yang bertugas mengetik sesuai dengan standar yang ditetapkan.

Evaluasi kriteria, skala, dan target wajib dilakukan. Setelah perawat menentukan kriteria, skala dan target pada hari pertama, maka pada hari berikutnya perawat tinggal memilih skala yang sesuai dengan kondisi pasien, antara $1-5$, disesuaikan dengan kondisi pasien. Penggunaan teknologi dalam keperawatan bisa menjadi kebahagiaan dan derita, bahagia bagi pengembangan sistem dan derita bagi sistem yang belum siap menerapkan. Teknologi dapat menjawab hal-hal yang makin rumit dan juga dapat mempengaruhi 
kualitas hidup seseorang. Dengan semakin digunakannya teknologi dalam keperawatan seharusnya semakin meningkatkan kompetensi teknologi seperti 'caring' dalam keperawatan (Rozzano, Marquerite, 2001).

Penerapan dokumentasi keperawatan secara elektronik dapat dimulai dengan perubahan SDM yang ada dalam hal ini adalah perawat. Seluruh kalangan perawat baik perawat senior maupun perawat junior harus mampu mengikuti perkembangan teknologi. Sehingga dalam hal ini sangat dibutuhkan peranan kepala ruangan yang dapat memfasilitasi tiap perawat untuk dilakukan pelatihan terkomputerisasi.

\section{F. Penutup}

Keberhasilan dalam menciptakan budaya keselamatan pasien pasien tidak terlepas dari peran kepala ruangan yang sigap untuk menghadapi era serba teknologi. Penerapan dokumentasi secara elektronik dapat membantu kelancaran program pelayanan keperawatan jika terdapat kerjasama yang baik pada setiap struktur organisasi. 


\section{Daftar Pustaka}

Kuntoro, Agus. (2017). Buku Ajar Manajemen Keperawatan. Yogayakarta: Nuha Medika. Mangole, J.E. dkk. (2015). Hubungan Prilaku Perawat Dengan Pendokumentasian Asuhan Keperawatan di Cardiovaskular dan Brain Center RSUP Prof. Dr. R. D. Kandou Manado. Jurnal Keperawatan. Diakses dari http:// schoolar.google.co.id/pendokumentasianasuhankeperawatandicardiodanbraincenter.

Margiawih, Untung. (2017). Perkembangan Dokumentasi Keperawatan Secara Elektronik. Diakses dari http://academia.edu/34548702/ PerkembanganDokumentasi_Keperawatan_Secara_Elektronik.

Marquis, Bassie. (2010). Kepemimpinan dan Manajemen Keperawatan. Jakarta: Penerbit Buku Kedokteran EGC.

McEachen, Irene dan Koegh, Jim. (2018). Manajemen Keperawatan Demystified. Yogyakarta: Penerbit Andi.

Nursalam. (2016). Manajemen Keperawatan. Jakarta: Penerbit Salemba Medika.

Pribadi, Agung. (2009). Analisis Pengaruh Faktor Pengetahuan, Motivasi, dan Persepsi Perawat tentang Supervisi Kepala Ruang terhadap Pelaksanaan Dokumentasi Asuhan Keperawatan di Ruang Rawat Inap RSUD Kelet Provinsi Jawa Tengah di Jepara. Tesis. Diakses dari http://schoolar google.co.id/analisfaktorpelaksanaandokumentasi.

Sabarguna, S.B. (2009). Keselamatan dan Keamanan pada Rekam Medis Terkomputerisasi. Penerbit Universitas Indonesia: Jakarta.

Simamora, R. H. (2014). Buku Ajar Manajemen Keperawatan. Jakarta: Penerbit Buku Kedokteran EGC.

Simamora, R. H. (2013). Upaya Pembinaan Perawat Di Rumah Sakit Ngesti Waluyo Parakan Temanggung Jawa Tengah. Jurnal Keperawatan Soedirman,8(2).

Suarli, S dan Yahya Bahtiar. (2009). Manajemen Keperawatan. Erlangga: Jakarta.

Wirawan, E.A. (2013). Hubungan antara supervise Kepala Ruang Dengan Pendokumentasian Asuhan Keperawatan di Rumah Sakit Umum daerah Ambarawa. Jurnal Manajemen Keperawatan. Diakses dari http://schoolar.google.co.id/pendokumentasianasuhankeperawatandirumahsakit.

Yanti, R. I. dan Warsito, B.E. (2013). Hubungan Karakteristik Perawat, Motivasi, Dan Supervisi Dengan Kualitas Dokumentasi Proses Asuhan Keperawatan. Jurnal Keperawatan. Diakses dari http:// schoolar.google.co.id/dokumentasiasuhankeperawatan.

Yunita, H. N. (2015). Dokumentasi Keperawatan Secara Elektronik. Jurnal Keperawatan. Diakses dari http:// schoolar.google.co.id/dokumentasikeperawatansecaraelektronik. 
